\title{
KEUNTUNGAN USAHA NASI KUNING KIOS YU CHIA DI KELURAHAN BANJER KECAMATAN TIKALA KOTA MANADO
}

\author{
Novan Winokan \\ Vicky Richard B. Moniaga \\ Agnes Estephina Loho
}

\begin{tabular}{ll}
\hline Naskah diterima melalui Website Jurnal Ilmiah agrisosioekonomi@unsrat.ac.id & : Kamis, 09 Januari 2020 \\
Disetujui diterbitkan & : Sabtu, 11 Januari 2020 \\
\hline
\end{tabular}

\begin{abstract}
This study aims to determine how much profit from Yu Chia Kiosk yellow rice business in Banjer Village, Tikala District, Manado City. This research was conducted during November 2019. The data used in this study are primary data obtained from interviews with business owners. Data collection methods used in this study were direct interviews with yellow rice business owners in the form of cost, price, and quantity of yellow rice products. Data analysis used in this study was descriptive data analysis and presented in the form of tables and profit analysis. The results of the study showed that the profit gained from this business was $R$ p. 628,915 per day. ${ }^{*}$ eprm*
\end{abstract}

Keywords: yellow rice, profit, Banjer Urban Village

\begin{abstract}
ABSTRAK
Penelitian ini bertujuan mengetahui berapa besar keuntungan dari usaha nasi kuning Kios Yu Chia di Kelurahan Banjer, Kecamatan Tikala, Kota Manado. Penelitian ini dilaksanakan selama bulan November tahun 2019. Data yang digunakan dalam penelitian ini adalah data primer yang diperoleh dari hasil wawancara dengan pemilik usaha. Metode pengumpulan data yang digunakan dalam penelitian ini adalah wawancara langsung pada pemilik usaha nasi kuning berupa data biaya, harga, dan jumlah produk nasi kuning. Analisis data yang digunakan dalam penelitian ini adalah analisis data deskriptif dan disajikan dalam bentuk tabel dan analisis keuntungan. Hasil penelitian menunjukkan keuntungan yang diperoleh dari usaha ini sebesar Rp. 628.915 per hari. ${ }^{*}{ }^{2}{ }^{*}{ }^{*}$
\end{abstract}

Kata kunci: nasi kuning, keuntungan, Kelurahan Banjer

\section{PENDAHULUAN}

Sektor pertanian mampu memberikan kontribusi yang sangat besar dalam proses pertumbuhan ekonomi negara. Hal ini seiring dengan proses pembangunan dan meningkatnya sektor-sektor yang lain. Sasaran pertumbuhan sektor pertanian tersebut tergolong dalam sasaran pertumbuhan yang cukup tinggi (Mokodongan, 2017).
Pada dasarnya agroindustri merupakan industri yang berbasis pertanian guna menambah nilai dari komoditi pertanian dan menyempurnakan hasil pertanian. Mengingat komoditi pertanian memiliki ciri khas yaitu mudah rusak sehingga perlu untuk dikonsumsi atau diolah terlebih dahulu, maka peran dari agroindustri sangat perlu dilakukan (Soekartawi, 2001). 
Produk pertanian dapat memberi keuntungan dan nilai tambah yang lebih jika produk tersebut diolah melalui berbagai proses produksi. Proses mengubah input menjadi output, yaitu bagaimana mengolah bahan baku menjadi produk sehingga memiliki nilai tambah dan keuntungan. Salah satu produk pertanian yang digunakan sebagai bahan baku adalah beras, yang digunakan untuk membuat berbagai jenis makanan dan kue (Barmawi, 2017).

Bisnis makanan (kuliner) merupakan salah satu bisnis yang dewasa ini berkembang pesat dan sudah banyak pelaku usaha yang mendapatkan keuntungan yang besar dari usaha kuliner ini. Berdasarkan hasil sensus BPS Kota Manado tahun 2018, terdapat 146 restoran dan 322 rumah makan yang ada di Kota Manado, dimana terjadi peningkatan dari tahun 2017 yaitu 111 restoran dan 146 rumah makan. Data ini menunjukkan bahwa bisnis kuliner di daerah Kota Manado sedang berkembang pesat.

Nasi kuning adalah salah satu makanan khas Indonesia yang terbuat dari beras yang dimasak bersama dengan kunyit serta santan dan rempah-rempah. Nasi kuning merupakan menu wisata kuliner yang banyak diminati oleh masyarakat di Kota Manado dan salah satu kuliner ciri khas Kota Manado. Hal ini menyebabkan banyak orang yang membuka usaha penjualan nasi kuning di Kota Manado. Nasi kuning selain banyak disukai oleh masyarakat, bahan bakunya mudah didapat dan proses produksinya tidak sulit karena tidak membutuhkan waktu yang lama ataupun alat yang khusus. Nasi kuning biasanya hanya sebagai menu sarapan, karena mengandung karbohidrat yang tinggi dan menjadi sumber energi untuk memulai aktivitas masyarakat.

Beberapa bisnis kuliner nasi kuning di Kota Manado sudah berdiri cukup lama dan terkenal sampai di luar daerah Sulawesi Utara. Hal ini menunjukkan bahwa bisnis ini memiliki keuntungan yang cukup menjanjikan dan bisa bertahan lama. Tetapi umumnya pengusaha nasi kuning di Kota Manado hanya menjadikan nasi kuning sebagai barang dagang konsumsi yang tujuannya untuk memenuhi kebutuhan keluarga sehari-hari dan tidak memperhatikan berapa nominal laba yang dihasilkan. Salah satunya adalah penjual nasi kuning yang ada di Kota Manado di Kelurahan Banjer, Kecamatan Tikala. Agar suatu usaha bisnis bisa bertahan lama dan berkembang produsen maka perlu diketahui berapa biaya nominal keuntungan yang diperoleh sehingga perlu dilakukan perhitungan pendapatan dan pengeluaran.

Berdasarkan latar belakang di atas, penulis tertarik untuk mengetahui berapa keuntungan usaha nasi kuning yang ada di kelurahan Banjer, kecamatan Tikala, Kota Manado.

\section{Rumusan Masalah}

Berdasarkan latar belakang yang telah di kemukakan, maka yang menjadi permasalahan dalam penelitian yaitu "Bagaimana keuntungan usaha nasi kuning Kios Yu Chia di kelurahan Banjer, kecamatan Tikala, Kota Manado?

\section{Tujuan Penelitian}

Mengetahui berapa besar keuntungan dari usaha nasi kuning Kios Yu Chia di Kelurahan Banjer, Kecamatan Tikala, Kota Manado.

\section{Manfaat Penelitian}

Manfaat dari penelitian ini untuk memberikan informasi dan masukan kepada usaha nasi kuning dalam mengembangkan usaha serta dapat dijadikan sebagai bahan referensi untuk penelitian yang terkait dengan keuntungan usaha.

\section{METODE PENELITIAN}

\section{Waktu dan Tempat Penelitian}

Penelitian ini dilaksanakan di Kelurahan Banjer, Kecamatan Tikala, Kota Manado selama bulan November 2019.

\section{Metode Pengumpulan Data}

Metode pengumpulan data yang digunakan dalam penelitian ini adalah wawancara langsung berupa data biaya, harga, dan jumlah produk nasi kuning. 


\section{Metode Analisis Data}

Analisis data yang digunakan dalam penelitian ini adalah analisis data deskriptif dan disajikan dalam bentuk tabel, sedangkan untuk mengetahui berapa besar tingkat keuntungan akan digunakan analisis keuntungan, yaitu:

dimana :

$$
\begin{array}{ll}
\pi & =\mathrm{TR}-\mathrm{TC} \\
\mathrm{TR} & =\mathrm{P} y \cdot \mathrm{Y} \\
\mathrm{TC} & =\mathrm{Px} \cdot \mathrm{X}
\end{array}
$$

$$
\begin{aligned}
& \pi=\text { profit } \text { (keuntungan) } \\
& \mathrm{TR}=\text { total penerimaan } \\
& \mathrm{TC}=\text { total biaya } \\
& \mathrm{Py}=\text { harga } \text { output } \\
& \mathrm{Y}=\text { jumlah } \text { output } \\
& \mathrm{Px}=\text { harga } \text { input } \\
& \mathrm{X}=\text { jumlah } \text { input }
\end{aligned}
$$

\section{Variabel Yang Diteliti.}

Variabel yang dihitung dalam keuntungan nasi kuning ini yaitu:

a. Karakteristik pengusaha atau produsen

Meliputi umur, jenis kelamin, pendidikan dan lama usaha.

b. Bahan Baku

Bahan baku adalah bahan dasar yang tesedia dan dipakai dalam proses produksi.

a) Mekanisme pengambilan bahan baku yaitu tempat pengambilan bahan baku yang digunakan dalam proses produksi.

b) Jumlah bahan baku yaitu jumlah yang dipergunakan dalam setiap proses produksi (Liter).

c. Tenaga Kerja

Tenaga kerja yang digunakan didalam industry ini adalah tenaga kerja keluarga sebanyak dua orang. Variabel ini diukur dalam satuan orang dan upah tenaga kerja diukur dalam satuan rupiah per jam.

d. Biaya

Keseluruhan biaya yang dikeluarkan dalam pengolahan nasi kuning.

Variabel ini diukur dalam satuan rupiah, meliputi:

a) Biaya tetap

- Biaya penyusutan alat

b) Biaya Variabel

- Bahan baku (Rp)

- Bahan penolong (Rp)

- Biaya tenaga kerja (Rp/Jam) e. Volume Produksi

Volume produksi adalah hasil yang diperoleh industry dari proses produksi (Bks/bulan).

f. Penerimaan

Penerimaan yaitu hasil perkalian antara jumlah produksi nasi kuning dengan harga jual $(\mathrm{Rp} / \mathrm{Bks})$

g. Keuntungan

Keuntungan Usaha yaitu sejumlah uang yang di peroleh pengusaha rumah makan yang berasal dari transaksi sampingan atau transaksi yang jarang terjadi dari semua transaksi

h. Pemasaran

Mekanisme pemasaran yaitu proses pemasaran produksi dari produsen ke konsumen.

Harga adalah harga jual dari produk nasi kuning yang dihasilkan/Rp/bungkus. Variabel ini diukur dalam satuan rupiah per bungkus.

i. Modal

Barang barang dan uang yang digunakan dalam pengelolaan nasi kuning, variable ini diukur dalam satuan rupiah.

j. Biaya

Keseluruhan biaya yang dikeluarkan dalam pengolahan nasi kuning.

Variabel ini diukur dalam satuan rupiah, meliputi:

a) Biaya tetap

- Biaya penyusutan alat

b) Biaya Variabel

- Bahan baku (Rp)

- Bahan penolong (Rp)

- Biaya tenaga kerja (Rp/Jam)

\section{HASIL DAN PEMBAHASAN}

\section{Gambaran Umum Kios Nasi Kuning Yu Chia}

Kios nasi kuning Yu Chia merupakan salah satu industri rumah tangga yang terletak di Kelurahan Banjer. Kios nasi kuning ini mulai dirintis sejak tahun 2014 oleh keluarga KartonoSupit. Awal usaha ini hanya merupakan usaha dari Ibu Rumah tangga yang mulai dirintis oleh Ibu Rumah tangga. Selama enam bulan usaha ini 
masih belum dikenal sehingga penjualan masih berkisar $3 \mathrm{~kg}$ beras perhari namun tidak menyerah dengan kondisi ini. Namun dengan berkembangnya pengenalan konsumen akan kekhasan dari nasi kuning ini usaha ini mulai mengalami peningkatan permintaan. Saat ini untuk melayanai permintaan konsumen dan pelanggan bahan baku yang dibutuhkan minimal $15 \mathrm{~kg}$ beras hingga $40 \mathrm{~kg}$ jika ada permintaan khusus. Sejalan dengan peningkatan usaha, maka Bapak keluarga juga meninggalkan pekerjaan yang lama dan mulai menekuni kios ini bersama dengan Ibu.

Pengelolaan kios Yu Chia ini bersifat usaha keluarga dengan penggunaan tenaga kerja sepenuhnya anggota keluarga. Bapak dan Ibu keluarga saling membantu dalam pengelolaannya mulai dari persiapan bahan baku, bahan penolong hingga proses pengolahan menjadi nasi kuning dan proses penjualan. Penjulan nasi kuning ini hanya menggunakan halaman rumah dengan kios yang dibangun di muka rumah tinggal. Kios ini mulai melayani konsumen dan pelanggan pada jam 06.00 - 09.00 pagi. Disamping menjual produk mereka di kios banyak juga yang memesan dalam bentuk kemasan, baik dalam kemasan kertas, mika, sterofoam, ataupun wadah plastik. Harga berkisar Rp 10.000 hingga Rp 20.000 tergantung kemasan dan banyaknya nasi kuning.

Keistimewaan dari nasi kuning ini menggunakan bahan baku yang berkualitas dengan toping semur daging, abon ikan cakalang, bawang merah, laksa, kripik kentang, dan juga kerupuk udang. Keistimewaan rasa ini menyebabkan pelanggan yang datang bukan hanya di sekitar lokasi tapi dari luar lokasi seperti Malalayang, Maumbi, Kelurahan sekitar, bahkan perkantoran.

\section{Proses Pengolahan Nasi kuning}

Nasi kuning yang dijual di Kios Yu Chia terdiri dari beberapa bagian. Bagian utama nasi kuning dengan toping semur daging, abon ikan cakalang, bawang merah, laksa, dan kripik kentang juga kerupuk udang. Kegiatan pengolahan mulai jam 02.00 pagi hingga pukul 05.30.

\section{Proses Pembuatan Nasi Kuning}

Proses pembuatan nasi kuning merupakan kegiatan yang paling banyak memakan waktu dengan proses yang lebih kompleks dibandingkan dengan yang lainnya. Proses awal mulai pencucian beras kemudian dilanjutkan dengan menanaknya bersama santan yang telah dicampur air kunyit juga diberikan sereh dan daun pandan di wajan kemudian dikukus di Dandang hingga matang. Beras yang digunakan adalah beras merek dua merpati. Setelah nasi matang, dimasukkan ke dalam pemanas.

\section{Proses Pembuatan Sambal}

Bahan baku pembuat sambal berupa bawang putih, bawang merah, cabe, dan tomat diblender kemudian digoreng ditambah gula merah, cabe merah dan ajinomoto. Penggorengan sambal dibuat hingga kering sehingga memakan waktu hingga 2 jam dengan api sedang.

\section{Pembuatan Abon Cakalang}

Ikan cakalang awalnya dikukus hingga matang kemudian dihaluskan. Bumbu bawang putih dan bawang merah dihaluskan kemudian digoreng hingga harum kemudian dimasukkan kecap manis, ketumbar dan gula merah kemudian ikan cakalang hingga kering ditambahkan garam dan penyedap rasa.

\section{Pembuatan Semur Daging}

Daging yang digunakan adalah daging sapi dengan mengambil bagian paha. Daging, kentang dan bawang bombay diiris kecil-kecil. Bawang putih yang telah dihaluskan ditumis kemudian dimasukan daging, kentang, bawang Bombay, jintar, ketumbar, kecap manis, garam dan bumbu penyedap rasa (masako) hingga masak.

\section{Pembuatan Laksa}

Laksa yang digunakan adalah laksa merek Padamu. Laksa direndam dalam air hingga lembut dan dipotong. Bawang putih dan bawang merah digoreng hingga harum kemudian dimasukan kecap manis, garam dan bumbu penyedap rasa (masako) dan laksa dan dimasak hingga lembut.

\section{Pembuatan Kentang Goreng}

Setelah kentang dikupas dan diparut. Kentang yang telah diparut dicuci berulangulang hingga air menjadi jernih. Kegiatan selanjutnya menggoreng kentang hingga kuning keemasan.

\section{Pembuatan Bawang Goreng}

Bawang goreng yang telah diiris dicampur sedikit garam kemudian digoreng hingga berwarna coklat muda. 


\section{Biaya Produksi}

Dalam pengolahan nasi kuning dibutuhkan biaya sebagai penggerak dari aktivitas ini. Biaya yang dikeluarkan berupa biaya tetap (fixed cost) dan biaya tidak tetap (variable cost). Biaya tetap adalah biaya relatif tetap jumlahnya dan terus dikeluarkan walaupun produksi banyak atau sedikit. Contohnya biaya biaya penyusutan peralatan. Biaya tidak tetap adalah biaya yang besar kecilnya di pengaruhi oleh produksi yang di peroleh. Contohnya biaya bahan baku, bahan penolong dan tenaga kerja. Berikut ini biaya yang dikeluarkan pada pengolahan Nasi kuning.

\section{Biaya Variabel}

Biaya variabel yang terjadi pada pembuatan nasi kuning adalah biaya pengeluaran seluruh pembuatan komponen nasi kuning dan tenaga kerja.

\section{a. Biaya Bahan Nasi Kuning}

Bahan baku utama dalam pembuatan nasi kuning adalah beras. Jumlah beras yang digunakan dalam analisis ini adalah jumlah minimal pembuatan/hari.

\begin{tabular}{lccrr}
\multicolumn{6}{c}{ Tabel 1. Biaya Pembuatan Nasi Kuning } \\
\hline \multicolumn{1}{c}{ Bahan } & Jumlah & Satuan & Harga (Rp) & Biaya (Rp) \\
\hline Beras & 15 & $\mathrm{~kg}$ & 10.750 & 161.250 \\
Kunyit & 1 & $\mathrm{~kg}$ & 10.000 & 10.000 \\
Kelapa & 6 & buah & 5.000 & 15.000 \\
Sereh & 5 & ikat & 2.000 & 10.000 \\
Lengkuas & 0,2 & $\mathrm{~kg}$ & 18.000 & 3.000 \\
Pandan & 3 & lembar & 350 & 1.050 \\
\hline \multicolumn{7}{c}{ Total (Rp.) } & & 215.300 \\
\hline
\end{tabular}

Tabel 1 menunjukkan bahwa biaya beras merupakan biaya terbesar dalam pembuatan nasi kuning. Hal ini karena beras merupakan bahan baku utama dalam pembuatan nasi kuming. Total biaya pembuatan nasi kuning sebesar Rp 202.250.

\section{b. Biaya Bahan Sambal}

Biaya pembuatan sambal merupakan pengeluaran untuk pembelian bawang putih, bwang merah, cabe, tomat, gula merah, kecap manis, ajinomoto. Rincian biaya dapat dilihat pada Tabel 2.

\begin{tabular}{lccrr}
\multicolumn{6}{c}{ Tabel 2. Biaya Pembuatan Sambal } \\
\hline \multicolumn{1}{c}{ Bahan } & Jumlah & Satuan & Harga & Biaya \\
\hline Bawang Putih & 0,2 & $\mathrm{~kg}$ & 40.000 & 8.000 \\
Bawang Merah & 0,4 & $\mathrm{~kg}$ & 40.000 & 16.000 \\
Cabe & 3 & $\mathrm{~kg}$ & 45.000 & 135.000 \\
Gula merah & 1 & $\mathrm{buah}$ & 20.000 & 20.000 \\
Tomat & 3 & $\mathrm{~kg}$ & 4.000 & 12.000 \\
Ajinomoto & 0,4 & pak(250gr) & 9.500 & 3.800 \\
Kecap Manis & 0,1 & Botol & 19.500 & 1.950 \\
\hline Total (Rp.) & \multicolumn{5}{c}{196.750} \\
\hline
\end{tabular}

Tabel 2 menunjukkan bahwa pengeluran untuk biaya cabe merupakan biaya terbesar karena cabe merupakan bahan baku pembuatan sambal.

\section{c. Biaya Bahan Abon}

Pengeluaran untuk biaya pembuatan abon berupa cakalang, bawang putih, bawang merah, kecap manis, ketumbar, dan bumbu penyedap rasa (Ajinomoto). Rincian biaya dapat dilihat pada Tabel 3.

\begin{tabular}{lcccc}
\multicolumn{6}{l}{ Tabel 3. Biaya Pembuatan Abon } \\
\hline Bahan & Jumlah & Satuan & Harga & Biaya \\
\hline Cakalang & 3 & Ekor & 50.000 & 150.000 \\
Bawang Putih & 0,2 & $\mathrm{Kg}$ & 45.000 & 9.000 \\
Bawang merah & 0,3 & $\mathrm{Kg}$ & 40.000 & 12.000 \\
Kecap manis & 0,3 & Botol & 19.500 & 5.850 \\
Ketumbar & 0,25 & bungkus & 4.200 & 1.050 \\
Ajinimoto & 0,2 & Pak (250gr) & 9.500 & 1.900 \\
\hline Total (Rp.) & \multicolumn{5}{c}{} & 179.800 \\
\hline
\end{tabular}

Tabel 3 menunjukkan bahwa bahan baku utama cakalang merupakan biaya terbesar yang dikeluarkan untuk pembuatan abon cakalang sedangkan bwang putih merupakan pengeluaran terkecil karena hanya merupakan penyedap dalam pembuatan abon ini.

\section{d. Biaya Bahan Semur Daging}

Biaya pembuatan semur daging berupa biaya pengeluaran untuk pembelian daging sapi, kentang, bawang putih, bawang Bombay, kecap manis, jintar, ketumbar, masako, dan garam dengan perincian biaya yang dituangkan dalam Tabel 4 .

Tabel 4. Biaya Pembuatan Semur Daging

\begin{tabular}{lrlrr}
\hline \multicolumn{1}{c}{ Bahan } & Jumlah & Satuan & Harga & Biaya \\
\hline Daging & 2 & $\mathrm{Kg}$ & 120.000 & 240.000 \\
Kentang & 2,5 & $\mathrm{Kg}$ & 15.000 & 37.500 \\
Bawang putih & 0,15 & $\mathrm{Kg}$ & 45.000 & 6.750 \\
Bawang bombay & 2 & Butir & 5.000 & 10.000 \\
Kecap Manis & 0,3 & Botol & 19.500 & 5.850 \\
Jintar & 0,75 & Bungkus & 4.200 & 3.150 \\
Garam & 0,1 & Bungkus & 500 & 50 \\
Ketumbar & 0,75 & Bungkus & 4.200 & 3.150 \\
Masako & 3 & Saset & 500 & 1.500 \\
\hline Total (Rp.) & & & & 307.950 \\
\hline
\end{tabular}


Tabel 4 menunjukkan bahwa bahan baku utama dalam pembuatan semur daging adalah daging sapi sedangkan pelengkap rasa garam merupakan biaya yang terkecil.

\section{e. Biaya Bahan Laksa}

Laksa merupakan pelengkap yang tidak bisa kalau tidak ada karena akan mengurangi kenikmatan nasi kuning. Pengeluaran untuk laksa dapat dilihat pada Tabel 5.

\begin{tabular}{|c|c|c|c|}
\hline & Komponen Biaya & Biaya (Rp) & Biaya Total (Rp) \\
\hline \multirow{11}{*}{$\begin{array}{l}\text { Paket Nasi } \\
\text { Kuning }\end{array}$} & Nasi kuning & 215.300 & \\
\hline & Sambal & 196.750 & \\
\hline & Abon & 179.800 & \\
\hline & Semur daging & 307.950 & \\
\hline & Laksa & 66.150 & \\
\hline & Keripik kentang & 225.000 & \\
\hline & Bawang goreng & 240.000 & \\
\hline & Kerupuk & 57.000 & \\
\hline & Minyak Kelapa (L) & 43.000 & \\
\hline & Gas & 27.000 & \\
\hline & Kertas Bungkus & 18.900 & \\
\hline \multirow{3}{*}{ Tenaga Kerja } & & Sub total & 1.576 .850 \\
\hline & Proses masak & 112.500 & \\
\hline & Penjualan & 75.000 & \\
\hline & Sub Total & 187.500 \\
\hline \multicolumn{2}{|c|}{ Penyusutan alat/hari } & 6.735 & 6.735 \\
\hline \multicolumn{2}{|l|}{ Biaya Total } & 1.771 .085 & 1.771 .085 \\
\hline
\end{tabular}

\section{Penerimaan Nasi kuning}

Penerimaan merupakan keuntungan yang diperoleh sebelaum mempertimbangkan biaya. Penerimaan diperoleh dari jumlah penjualan dikalikan dengan harga. Harga yang terjadi di kios Yu Chia bervariasi dari Rp 15.000 hingga Rp 20.000, tergantung dari konsumen. Kebanyakan yang memesan dalam kemasan adalah orang kantoran atau pesanan untuk dibawa ke luar daerah. Hal ini mengakibatkan adanya subsidi silang pada konsumen. Harga yang ditetapkan oleh pengelola untuk konsumen yang datang makan di tempat lebih murah dengan alasan kekerabatan. Penerimaan Kios Yu Chia dapat dilihat pada Tabel 9.

Tabel 9. Penerimaan Nasi Kuning Dengan Variasi Harga

\begin{tabular}{lrrr}
\hline Penerimaan & \multicolumn{3}{c}{ Simulasi Harga (Rp) } \\
\hline Jumlah Bungkus(Q) & 150 & 150 & 150 \\
Harga(P) (Rp) & 10.000 & 15.000 & 20.000 \\
\hline Penerimaan (R)(Rp) & 1.500 .000 & 2.250 .000 & 3.000 .000 \\
\hline
\end{tabular}

Tabel 9 menunjukkan bahwa semakin tinggi harga yang ditentukan semakin tinggi penerimaan yang akan diperoleh.

\section{Keuntungan Nasi Kuning}

Keuntungan dari nasi kuning adalah keuntungan bersih yang diperoleh dari selisih antara total penerimaan dan total biaya. Keuntungan nasi goring kuning dapat dilihat pada Tabel 10.

\begin{tabular}{|c|c|c|}
\hline Harga & Kuantitas (\%) & Jumlah (Rp.) \\
\hline 10.000 & 10 & 150.000 \\
\hline 15.000 & 60 & 1.350 .000 \\
\hline 20.000 & 30 & 900.000 \\
\hline Penerimaan $(\mathrm{A})$ & & 2.400 .000 \\
\hline Biaya (B) & & 1.771 .085 \\
\hline Keuntungan (A-B) & & 628.915 \\
\hline
\end{tabular}

Tabel 10 menunjukkan bahwa keuntungan yang diperoleh sebesar Rp 628.915 dalam sehari, dengan mayoritas harga yang dijual adalah Rp. 15.000 sebesar 60\%. dengan jumlah sebesar Rp. 1.350.000.

\section{KESIMPULAN DAN SARAN}

\section{Kesimpulan}

Kesimpulan dari penelitian ini adalah keuntungan yang diperoleh dari Kios Nasi Kuning Yu Chia sebesar Rp. 628.915 yang berasal dari penerimaan sebesar Rp. 2.400.000/hari.

\section{Saran}

Berdasarkan hasil penelitian, maka saran yang dapat diberikan untuk kemajuan industri ini adalah disarankan kios $\mathrm{Yu}$ Chia untuk mempertahankan kualitas produksinya dan menggunakan jasa e-commerce untuk memperluas jangkauan pemasarannya sehingga jumlah permintaan meningkat dan memperoleh keuntungan yang maksimal.

\section{DAFTAR PUSTAKA}

Barmawi. 2017. Analisis Keuntungan Usaha Martabak Telur Di Matangglumpang dua Kecamatan Peusangan Kabupaten Bireuen. Jurnal program Studi Agribisnis Fakultas Pertanian Unversitas Almuslim. Aceh.

Mokodongan. W. 2017. Analisis Nilai Tambah Agroindustri Rumah Tangga Produk Keripik Pisang (Studi Kasus Kecamatan Malalayang). Skripsi Fakultas Pertanian Universitas Sam Ratulangi. Manado.

Soekartawi. 2001. Pengantar Agroindustri PT. Raja Grafindo Persada. Jakarta. 